\title{
Pengaruh Kinerja Guru Biologi Terhadap Prestasi Belajar Siswa SMA Kabupaten Sumba Barat Daya
}

\author{
Oktavianus Deke \\ Program Studi Pendidikan IPA, Sekolah Tinggi Keguruan dan Ilmu Pendidikan, Weetebula, Jln. \\ Mananga Aba, NTT. Indonesia 87252 \\ *Corresponding Author e-mail: oktavianusdeke86@gmail.com
}

Received: February 2020; Revised: March 2020; Published: March 2020

\begin{abstract}
Abstrak
Penelitian ini bertujuan untuk mengetahui pengaruh kinerja guru biologi terhadap prestasi belajar siswa SMA. Penelitian ini adalah penelitian survei. Sampelnya adalah guru biologi yang mengajar kelas X dan XI berjumlah 20 orang, setiap guru memilih satu kelas untuk sampel. Pengumpulan data menggunakan angket dan tes. Analisis data menggunakan analisis deskriptif regresi. Hasil analisis data menunjukkan bahwa ada pengaruh signifikan antara kinerja guru terhadap prestasi belajar siswa
\end{abstract}

Kata Kunci: Kinerja Guru, Hasil Belajar Siswa

\section{The Effect of Biology Teacher Performance on Senior High School Students' Learning Achievements in Southwest Sumba District}

\begin{abstract}
This study aims to find out the effect between biology teacher's performances and student's learning achievements of senior high school (SHS). The sample consisted of biology teachers teaching in Grades X and XI with a total of 20 teachers and students of Grades X and XI. The data were collected through questionnaires and tests. The data were analyzed by means of the regresi analisis technique. The results of the path analysis show that there is a significant effect between biology teacher's performances and student's learning achievement.
\end{abstract}

Keywords: Teacher Performance, Student's Learning Achievements

How to Cite: Deke, O. (2020). Pengaruh Kinerja Guru Biologi Terhadap Prestasi Belajar Siswa SMA Kabupaten Sumba Barat Daya. Jurnal Penelitian dan Pengkajian Ilmu Pendidikan: e-Saintika, 4(1), 62-67. doi:https:// doi.org/10.36312/e-saintika.v4i1.205

https:// doi.org/10.36312/e-saintika.v4i1.205

Copyright $\odot$ 2020, Deke This is an open-access article under the CC-BY-SA License.

\section{PENDAHULUAN}

Pendidikan formal menduduki posisi yang sangat penting dalam sektor pembangunan demi peningkatan kualitas sumber daya manusia. Sekolah merupakan salah satu bentuk pendidikan formal yang didalamnya terdapat berbagai unsur-unsur seperti pendidik, siswa, kurikulum, materi pelajaran, metode pembelajaran, media pembelajaran, sarana dan prasarana pembelaaran. Semua unsur-unsur tersebut menjadi bagian yang sangat penting untuk mencapai tujuan pembelaaran yang diinginkan. Dari semua unsur tersebut, guru adalah salah satu unsur yang sangat mempengaruhi demi tercapainya tujuan pembelajaran. 
Guru profesional adalah guru yang berperan sebagai yaitu informator, organisator, motivator, manajer, inisiator, transmiter, fasilatator, mediator dan evaluator (Sadirman, 2011). Keberhasilan pendidikan di sekolah dipengaruhi oleh kesiapan guru dalam merencanakan pembelajaran dengan menyiapkan berbagai alat bantu yang dibutuhkan untuk mendukung pelaksanaan pembelaaran dan bagaimana cara guru menyampaikan materi pelajaran kepada siswa melalui kegiatan pembelajaran sehingga siswa dapat mencapai tujuan pembelajaran yang ditentukan. Guru sebagai pembelajaran di sekolah, kehadiran guru di sekolah merupakan senter bagi siswa untuk melihat terang sehingga guru sebagai pengelola pembelajaran harus mendesain pembelajaran dengan baik sehingga penyajian materi berlangsung dengan teratur dan adanya interaksi positif dengan siswa pada waktu proses pembelajaran hasilnya sesuai dengan tujuan yang ditetapkan.

Wiratama, Yudana, \& Candiasa (2013) mengemukakan bahwa peristiwa yang terjadi di lapangan menunjukkan bahwa ada guru yang tidak memanfaatkan watu luang yang ada untuk berkreatif. Hal lain juga yang menunjukkan guru tidak memanfaatkan watu luang adalah kurangnya motivasi dalam berkreatif untuk memikirkan ide-ide pembelaaran dan membuat media pembelajaran yang mendukung materi ajar sehingga memudahkan siswa dalam pemahaman materi pelajaran. Disiplin waktu dalam mengajar yang kurang seperti yang ditemukan dilapangan masih ada sejumlah guru datang terlambat di sekolah sehingga waktu mengajar terlambat, ada guru menitipkan catatan keada siswa sampai jam pelajaran selesai, ada guru yang datang dan pulang semaunya.

Berdasarkan hasil pengamatan selama mengajar di SMA Negeri 1 Wewewa Timur, Kabupaten Sumba Barat Daya, Nusa Tenggara Timur, terlihat bahwa ada guru yang tidak disiplin dalam melaksanakan tugasnya, seperti guru datang terlambat di sekolah sehingga mengganggu persiapan untuk mengajar, ada guru yang menitipkan catatan sampai jam pelajaran selesai, ada guru yang cenderung kurang memanfaatkan waktu yang ada untuk berkreativitas dalam dalam memikirkan dan membuat media pembelajaran, motivasi internal guru yang kurang dalam mempersiapkan materi pelajaran dan alat bantu (media pembelaaran) sehingga mempengaruhi kompetensi profesional guru dan tidak melakukan refleksi untuk melihat sejauh mana keberhasilan dalam mengajar untuk memperbaiki atau meningkatkan pembelajaran selanjutnya.

Supardi (2013) mengemukakan bahwa kinerja guru merupakan kemampuan seorang guru untuk merencanakan pembelaaran, melaksanakan pembelajaran dan melakukan penilaian hasil belajar siswa dan ada rasa memiliki siswa yang diajar untuk meningkatkan hasil belajar siswa tersebut. Guru yang berkinerja baik adalah guru yang memiliki kemampuan untuk merencanakan pembelajaran seperti membuat rencana pelaksanaan pembelajaran, mendesain strategi yang digunakan dalam mengajar, membuat dan mempersiapkan media pembelajaran yang dibutuhkan dan lain sebagainya. Selanjutnya, melaksanakan pembelajaran sesuai rencana yang dibuat serta melakukan penilaian hasil pembelajaran yang berkaitan dengan proses pembelajaran maupun hasil belajar siswa. Artinya, guru yang kompoten secara profesional adalah guru yang dapat menciptakan iklim belajar yang kondusif, dapat mengembangkan strategi pembelajaran serta adanya umpan balik dan penguatan.

Penelitian yang relevan dengan penelitian ini oleh Subranur Tesa Trianda (2014) dengan judul Pengaruh Kinerja Guru Terhadap Hasil Belajar Peserta Didik 
Kelas X Pada Mata Pelajaran Ekonomi di SMA, tetapi indikator kinerja yang diteliti hanya terbatas pada perencanaan pembelajaran, pelaksanaan pembelajaran dan penilaian hasil belajar pada siswa. Sedangkan dalam penelitian ini mengakaji lebih mendalam tentang perencanaan pembelajaran dengan melihat kondisi awal siswa terhadap pemahaman materi sehingga dapat merencanakan pembelajaran sesuai karakteristik siswa. Sedangkan pada pelaksanaan pembelajaran saya menggukan media pembelajaran yang memadai sesuai materi pelajaran sehingga tingkat pemahaman siswa lebih mendalam pelajaran.

\section{METODE}

Jenis Penelitian ini adalah penelitian survei. Penelitian ini dimulai dari bulan Januari sampai dengan Maret 2016 yang dilaksanakan di delapan (8) SMA yang tersebar di kabupaten Sumba Barat Daya, Nusa Tenggara Timur, yang terdiri dari 5 (Lima) SMA Negeri dan 3 (Tiga) SMA Swasta. Populasi dalam penelitian adalah semua guru biologi dan peserta didik SMA. Sedangkan sampel dalam penelitian adalah guru biologi yang mengajar kelas $X$ dan XI yang berjumlah 20 orang guru dan siswa kelas $X$ dan XI dengan masing-masing guru memilih satu kelas untuk dijadikan sampel penelitian dengan teknik purposive sampling.

Teknik pengumpulan data dalam penelitian ini adalah: (1) observasi dan dokumentasi untuk memperoleh data tentang kinerja guru biologi dengan cara mengamati perangkat pembelajaran, mengamati pelaksanaan pembelajaran dan penilaian hasil belajar siswa dan (2) tes untuk memperoleh data yang berkaitan dengan prestasi belajar siswa SMA. Teknik ini digunakan peneliti dengan membagikan soal tes kepada siswa kelas X dan kelas XI untuk dijawabnya.

Uji validitas dibagi menjadi dua yaitu pertama validitas ahli yaitu suatu uji dengan cara meminta pertimbangan ahli yang sesuai dengan instrumen untuk menilai indikator, sub indikator dan kesesuain item dan soal. Kedua yaitu validitas dengan melakukan uji coba di guru yang berjumlah 30 orang dan peserta didik yang berjumlah 35 orang yang tidak termasuk sampel. Selanjutnya dilakukan analisis item dan soal dengan menggunakan bantuan program komputer, yaitu SPSS versi 16.00 for windows. Setelah melalui proses analisis maka diketahui $r$ hitung. Apabila $r$ hitung $\geq 0,30$ maka item atau soal valid.

Sedangkan uji reliablitas instrumen dilakukan dengan menggunakan metode Alpha-Cronbach. Perhitungan dilakukan dengan bantuan SPSS versi 16.00 for windows. Reliabilitas diukur dengan skala alpha 0-1. Instrumen penelitian dapat dikatakan memiliki tingkat reliabilitas yang memadai jika koefisien Alpha-Cronbach lebih besar atau sama dengan 0,70.

Teknik analisis data yaitu analisis deskriptif dan analisis regresi. Untuk melihat gambaran atau kejelasan data menggunakan analisis deskriptif sedangkan untuk melihat pengaruh antar variabel menggunakan analisis regresi.

\section{HASIL DAN PEMBAHASAN}

Untuk melihat gambaran pengkategorian data menjadi sangat baik, baik, cukup baik, kurang dan sangat kurang maka dilakukan analisis deskriptif data tentang kinerja guru dan prestasi belajar siswa. Adapun hasil analisis data tersebut disajikan pada Tabel 1 berikut. 
Tabel 1. Rangkuman Kinerja Guru Biologi Dengan Kategori

\begin{tabular}{lll}
\hline Frekuensi & $\begin{array}{l}\text { Persentase } \\
(\%)\end{array}$ & Kategori \\
\hline 13 & 65,0 & Sangat Baik \\
6 & 30,0 & Baik \\
1 & 5,0 & Cukup Baik \\
- & - & Kurang \\
- & - & Sangat \\
& & kurang \\
\hline
\end{tabular}

Dari data pada Tabel 1 diatas dapat dikategorikan bahwa ada 13 orang guru biologi yang memiliki kinerja yang berada pada kategori sangat baik dengan persentase $65 \%$ dan 6 orang guru biologi memiliki kinerja guru yang berada pada kategori baik dengan persentase $30 \%$ serta 1 orang guru biologi memiliki kinerja yang berada pada kategori cukup baik. Dari hasil pengkategorian data tentang kenerja guru maka dapat disimpulkan bahwa kinerja guru SMA di Kabupaten Sumba Barat Daya, Nusa Tenggara Timur berada pada kategori sangat baik dan baik seperti disajikan Tabel 2.

Tabel 2. Rangkuman Prestasi Belajar Siswa Dengan Kategori

\begin{tabular}{lll}
\hline Frekuensi & Presentase & Kategori \\
\hline 6 & 30,0 & Sangat Baik \\
14 & 70,0 & Baik \\
- & - & Cukup Baik \\
- & - & Kurang \\
- & - & Sangat \\
& & kurang \\
\hline
\end{tabular}

Dari data pada Tabel 2 diatas dapat dikategorikan bahwa ada 6 kelas yang memiliki prestasi yang berada pada kategori sangat baik dengan persentase $30 \%$ dan 14 kelas berada pada kategori baik dengan persentase 70\%. Dari hasil pengkategorian data tentang prestasi siswa dapat disimpulkan bahwa prestasi belajar siswa SMA di Kabupaten Sumba Barat Daya, Nusa Tenggara Timur berada pada kategori baik.

Untuk mengetahui sejauh mana tingkat pengaruh kinerja guru terhadap prestasi belajar siswa maka dilakukan analisis regresi. Adapun hasil analisis data tersebut seperti pada Tabel 3 berikut.

Tabel 3. Hasil analisis regresi kinerja guru terhadap prestasi belajar peserta didik

\begin{tabular}{lllllll}
\hline Model & & $\begin{array}{l}\text { Sum of } \\
\text { Square }\end{array}$ & df & $\begin{array}{l}\text { Mean } \\
\text { Square }\end{array}$ & F & Sig. \\
\hline 1 & Regression & 58,769 & 1 & 58,769 & 18,182 & 0,000 \\
& Residual & 58,181 & 18 & 3,232 & & \\
& Total & 116,950 & 19 & & & \\
\hline
\end{tabular}

Berdasarkan hasil analisis regresi pada tabel 4 di atas didapatkan nilai signifikansi kinerja guru terhadap prestasi belajar siswa sebesar 0,000 atau nilai signifikansi $<0,05$. Hasil analisis tersebut dikatakan bahwa kinerja guru signifikan terhadap prestasi belajar siswa. Dengan demikian, dapat dismpulkan bahwa kinerja guru memberikan pengaruh terhadap prestasi belajar siswa. 
Berdasarkan hasil analisis data penelitian membuktikan bahwa kinerja guru biologi SMA di kabupaten Sumba Barat Daya, Nusa Tenggara Timur memiliki pengaruh terhadap prestasi belajar peserta didik. Kinerja guru merupakan faktor yang memiliki pengaruh signifikan terhadap prestasi belajar peserta didik. Hasil penelitian ini didukung oleh teori Kompri (2015: 55) menyatakan bahwa kinerja guru dapat terlihat jelas dalam pembelajaran yang diperlihatkan dari prestasi belajar peserta didik. Selanjutnya hasil penelitian yang mendukung penelitian ini adalah Subranur Tesa Trianda (2014). Hasil penelitian ini menyatakan bahwa terdapat pengaruh yang signifikan dan positif kinerja guru terhadap prestasi belajar siswa. Artinya guru memiliki peranan yang sangant penting dalam proses belajar siswa sehingga siswa dapat belajar dengan baik untuk mencapai tujuan yang diinginkan. Tercapainya keberhasilan siswa sangat dipengaruhi oleh kesiapan guru dalam merencanakan pembelajaran, melaksanakan pembelajaran dan menilai hasil belajar siswa. Keberhasilan siswa dalam belajar sangat dipengaruhi oleh strategi guru dalam melaksanakan pembelajaran sehingga perlu media pembelajaran untu membantu guru dalam mentranfer materi pelajaran kepada siswa. Siswa yang berhasil dalam pembelajaran memiliki prestasi belajar setelah melalui kegiatan proses belajar mengajar di sekolah. Oleh arena itu, kesiapan guru dalam merencanakan pembelajaran yang sesuai kondisi siswa dan penggunaan media pembelajaran yang memadai, melaksanakan pembelajaran dengan kondusif akan memberikan sumbangsi yang besar untuk keberhasilan siswa dalam belajar.

\section{KESIMPULAN}

Ada pengaruh yang signifikan kinerja guru biologi terhadap prestasi belajar siswa SMA di kabupaten Sumba Barat Daya, Nusa Tenggara Timur (NTT) dengan kontribusi sebesar 58,769\% dan sisanya dipengaruhi oleh faktor lain. Artinya kinerja guru memberikan pengaruh yang signifikan terhadap prestasi belajar siswa

\section{SARAN}

Bagi guru-guru SMA di kabupaten Sumba Barat Daya, Nusa Tenggara Timur diharapkan untuk dapat merencanakan dan melaksanakan pembelajaran serta melakukan penilaian hasil belajar siswa untuk meningkatkan kinerja. Selanjutnya perlu melakukan evaluasi program untuk memperbaiki kualitas pembelaaran. Bagi para Kepala Sekolah SMA di Kabupaten Sumba Barat Daya, Nusa Tenggara Timur untuk dapat memperhatikan dan mensejahterakan guru-guru di Sekolah dapat meningkatkan kinerja. Bagi Dinas Pendidikan dan Kebudayaan Kabupaten Sumba Barat Daya, Nusa Tenggara Timur dan pengelola pendidikan swasta diharapkan untuk terus melakukan supervisi setiap semester sehingga dapat memantau pembelajaran yang dilakukan guru dan diadakan kegiatan pelahatihan secara terus menerus untuk meningkatkan pengetahuan IPTEK bagi guru

\section{UCAPAN TERIMAKASIH}

Ucapan terima kasih terutama ditujukan kepada Pimpinan STKIP Weetebula dan Lembaga Misereor yang telah memberikan kesempatan untuk melanjutkan studi dan membiayai penulisan artikel ini. Juga kepada rekan rekan dosen STKIP Weetebula yang telah memberikan dukungan kepada penulis. 


\section{DAFTAR PUSTAKA}

Alber, S. R., \& Heward, W. L. (2001). Teaching students to Recruit Positive Attention. A Review and Recommendation. Jurnal of Behavioral Education, 10, 177-204.

Arianto, D. A. (2013). Pengaruh Kedisiplinan, Lingkungan Kerja, dan Budaya Kerja Terhadap Kinerja Tenaga Pengajar. Jurnal Economia, Universitas Islam Nahdlatul Ulama Jepara, Indonesia, 9, 191-200.

Asri, M., \& Tahir, L. B. (2015). The Effect of Personality Value of Principals toword Attitude, Discipline, Qualities and Communication of Work. Jurnal of Education and learning, Universitas Teknologi Malaysia. 9, 61-70.

Brooks, D. W., and Shell, D. F. (2006).Working memory, Motivation, and TeacherInitiated Learning. Jurnal of Science Education and Teknology, 15, 17-30.

Connie. (2013). The Influence of Professional Competence, Work Motivation, and Innovativeness on The Performance of Physics Techer, 2nd International Seminar on Quality and Affordable Education (ISQAE 2013), Universitas Negeri Jakarta. 133138

Hanafiah, N., \& Suhana, C. (2009). Konsep Strategi Pembelajaran.Bandung: PT. Refika Aditama.

Jihad, A., \& Haris, A. (2008). Evaluasi Pembelajaran. Jakarta: Multi Press.

Khairani. (2013). Pengaruh Budaya Organisasi dan Kinerja Guru Terhadap Prestasi Belajar Peserta Didik Sekolah Menengah Atas Negeri 1 Krueng Barona Jaya. Darusalam Banda Aceh, Program Pascasarjana, Universitas Asyah Kuala.

Kompri.(2015). Motivasi Pembelajaran, Perspektif Guru dan Siswa. Bandung: PT Remaja Rosdakarya

Moriera, H., Fox, K. R., and Spakers, A. C. (2002). Job Motivation Profiles of Physical Educator: theoretical Background and Instrument Development. Jurnal British Educational Research, 28, 845-861.

Nuchiyah, N. (2007). Pengaruh kepemimpinan Kepala Sekolah dan Kinerja Mengajar Guru Terhadap Prestasi Belajar Siswa.Jurnal Pendidikan dasar. 5.. 14-29.

Pattipawae, D. R. (2011). Penerapan Nilai-Nilai Dasar Budaya kerja dan PrinsipPrinsip Organisasi Budaya Kerja Pemerintah Dengan Baik dan Benar. Jurnal Sasi. 17, 31-44

Sadirman. (2011). Interaksi \& Motivasi Belajar Mengajar. Jakarta: PT. Raja Grafindo Persada.

Supardi. (2013). Kinerja Guru. Jakarta: Rajawali Pers. 